\title{
The Effect of Conscientiousness and Gender on Digital Game Addiction in High School Students
}

\begin{tabular}{ccc}
\hline Article Type & Received Date & Accepted Date \\
Research & 22.03 .2019 & 18.07 .2020 \\
\hline
\end{tabular}

\begin{abstract}
Ahmet Kesici*
Abstract

This study aims to investigate the effect of conscientiousness and gender on digital game addiction in high school students. This study has been conducted to 470 students from three vocational schools and four common high schools in Siirt in 2017-2018 academic year through a relational survey method. In this research, conscientiousness sub-dimension of The Big Five Inventory and Digital Game Addiction scale have been used. It has also been determined that conscientiousness and gender are significant predictors of digital game addiction, and both of the variables are able to explain approximately $12 \%$ of digital game addiction. Depending on this, this study has attempted to observe low level conscientiousness and gender (in case of being male) affect digital game addiction negatively in high school students. In addition to this, it has aimed to show that gender and low conscientiousness are the possible risk factors for students in term of digital game addiction. For this reason, the students' traits of conscientiousness, particularly of male students, must be developed. Sense of responsibility is related to conscientiousness. Therefore, the traits of conscientiousness might be developed by enhancing the adolescents' sense of responsibility, and hence some positive outcomes can be acquired against the digital game addiction.
\end{abstract}

Keywords: Conscientiousness, responsibility, digital game addiction, values education. 


\section{Lise Öğrencilerinde Sorumluluğun ve Cinsiyetin Dijital Oyun Bağımlılığına Etkisi}

$\begin{gathered}\text { Makale Türü } \\ \text { Araştırma }\end{gathered}$
$\begin{aligned} & \text { Başvuru Tarihi } \\ & 22.03 .2019\end{aligned}$
Ahabul Tarihi
18.07 .2020

Anahtar Sözcükler: Sorumluluk, kişilik, dijital oyun bağımlılığı, değerler eğitimi. 


\section{Introduction}

Personality can be defined as the sum of the consistently displayed traits by the individual that distinct him/her from others (Can, 2014). Some of the physical attributes that constitute the personality are innate. However, some other personality traits such as attitude, value, and purpose begin to take shape spontaneously through life experiences in the process. Personality (Sardoğan \& Karahan, 2011);

1. It contains the distinctive behaviors, unique to individual.

2. The consistency and the continuity of the behaviors can be mentioned

3. It is relatively lasting. However, it is a dynamic process that can evolve in the contextual context.

Many theories have been put forward to define the personality. One of these theories is the trait theory. In this approach, the personality is explained through the observatory behaviors and individual differences (Basım, Çetin \& Tabak, 2009). According to this theory, individual differences are reflected on the spoken language, that is, on words. Depending on this view, Goldberg and his friends have codified the words that reflect on the personality in a language and put these codes to factor analysis. Therefore, they have stated that personality is a kind of structure that consists of five dimensions. The model that defines personality with five traits is called as five-factor model of personality. These five traits are simply known as extroversion, agreeableness, conscientiousness, neuroticism and openness (Costa \& McCrae, 1995; Somer, 1998; Tatlllığlu, 2014). Some crosscultural studies have been carried out to support the validity of this model (Schmitt, Allik, McCrae, \& Benet-Martinez, 2007).

Conscientiousness includes the characteristics such as one's obedience, one's sense of responsibility, one's self-discipline and one's tendency to success. Sense of conscientiousness is translated as responsibility in Turkish since it means one's best efforts to fulfill a given task. It has been noted that the individuals with high level of conscientiousness are disciplined, attentive, willed to succeed while the ones with low level of conscientiousness are inattentive, disorganized and lazy (Costa \& McCrae, 1995). The exorbitant level of conscientiousness manifests itself as a distressing disorder that causes one to suffer from punctiliousness and tidiness in obsessive degrees. On the other hand, the low level of conscientiousness causes one to become flexible in one's reaching goals and moral manners (Costa, McCrae \& Dye, 1991; Somer, Korkmaz \& Tatar, 2004). For this reason, conscientiousness is a feature to be developed through training. Conscientiousness is associated with one aspect of ego strength. This dimension has a basic function under the drive's control. Therefore, conscientiousness has both developing and inhibiting sides (Costa, McCrae \& Dye, 1991; Somer, Korkmaz \& Tatar, 2004). In this respect, conscientiousness is thought to be associated with digital addiction (mobile phone addiction, internet addiction, game addiction in virtual platforms). Digital addiction is a problem that results from the drive control. It is the drive that causes one to keep using the digital tools excessively although it is known that the individual will suffer from physical, mental and social problems (Kesici \& Tunç, 2018).

Lately, digital game addiction, a kind of digital addiction has become a common problem that has particularly been experienced by the adolescents (Irmak \& Erdoğan, 2016). Adolescence is a period when abstract and logical thinking make progress in adolescents. In this period, the individual is ready to make decision and to have responsibility. Adolescence, a period that sets a balance between autonomy, freedom and responsibility in individuals is vital for the personality development as well (Acar, 2012). In fact, the researches that have been carried out have revealed the relation between the digital game addiction and the personality (Ayas, 2012; Charlton \& Danforth, 2010; Kim et al., 2008; Servidio, 2014).

Digital games that are played in virtual settings are places for entertainment that are limited by its own rules and independent of the real world (Garris, Ahlers \& Driskell, 2002). In virtual space, they are classified as console games, computer games, and online games. There are such various kinds as action, adventure, simulation, sport, strategy and network. They can be played with single or multiple players. Some games have communicative and interactive dimensions as well (Gürcan, Özhan \& Uslu, 2008). 
Games are used in education in terms of the fact that they create a secure place by making one feel relaxed, concentrated as well as increasing one's motivation and self-efficacy. Nowadays, digital games are used in the fields such as science, math, medicine, engineering, language learning, problem solving and developing strategically thinking skills (Bayırtepe \& Tüzün, 2007; Garris, Ahlers \& Driskell, 2002). Moreover, they are used to change some unwanted behaviors or to inform the individuals about various topics (Hewitt et al., 2001; Johnston, Massey \& Marker-Hoffman, 2012; Kato et al., 2008).

It has been argued that playing games has many benefits if not excessively. It helps one feel relaxed, gives one a sense of self-development and also enables one to meet one's social needs. Moreover, it helps develop one's eye-hand coordination, visual and spatial skills, problem solving and multi-task skills. It also enables one to develop one's cooperation skills and emphatic behaviors that are most cared by the parents (Gürcan, Özhan \& Uslu, 2008; Irmak \& Erdoğan, 2016; Prot et al., 2014). One's game addiction might be the case in point only if one does not control his will to play games and depending on this, if one's emotional, mental and social life is affected negatively by it (Young, 2009). DGA (Digital Game Addiction) is defined as "drive control disorder" that contains the symptoms such as not controlling the time for playing games, showing lack of interest to other activities, keeping playing games despite its negative effects and feeling tired psychologically in times of not playing games (Irmak \& Erdoğan, 2016). In the researches, conducted, it has been observed that various problems have arisen because of the DGA. It has been reported that DGA has caused social (at work, in spending free time, in education and in social relations) psychological (too much stress, isolation from real life, loneliness, decrease in academic success, increase in carelessness, aggressiveness, not handling the situation, decrease in verbal memory performance, and suicidal ideation) physiological (obesity, wrist-ache, neck-ache, hand-vibration syndrome, sleeping anomalies) problems (Griffiths, Kuss \& King, 2012).

In literature, DGA is commonly examined as behavioral addiction. However, APA (American Psychiatrists' Association) views DGA as a disorder of playing games online and encourages more studies to be done over it (Irmak \& Erdoğan, 2016). Nowadays, DGA is similarly regarded as a problem related to internet addiction (Nazlıgül et al., 2018). However, it is different from Internet addiction though DGA is a concept in relation to Internet addiction. This difference mostly depends upon gender. It is stated that males are particularly associated with DGA (Király et al, 2014). It is also noted in literature that gender is a striking element in relation to DGA. For this reason, it must be paid attention in the researches, conducted on DGA (Nazligül et al., 2018).

This study has been conducted to observe the relation between the conscientiousness, gender and DGA in high school students. It has also been aimed to see the impact of gender and conscientiousness, a type of personality trait, on the DGA.

Different concepts such as game addiction in virtual context, video game addiction, pathological game addiction, computer game addiction, online game addiction are used in literature. In this study, however, the DGA is used to describe the addiction related to playing games excessively in virtual context.

\section{Method}

In this study, relational survey model has been used. Through this model, it has been aimed to show how gender differences and the change in conscientiousness have affected the DGA (Karasar, 2014).

\section{Participants}

Present study was conducted in Siirt in 2017-2018 educational year. 470 students from three vocational schools (200 students) and four common high schools (270 students) participated in the study. While choosing the participants, convenience sampling method was applied. To reach the whole target population is challenging so convenience sample were formed according to accessibility. The convenience sample and study groups were formed according to accessibility (Kılıç, 2013). The data related to the participants are given in Table 1. 
Table 1

The distribution of the students with regard to gender and class

\begin{tabular}{llll}
\hline & & $\mathbf{N}$ & $\mathbf{\%}$ \\
\hline Gender & & & \\
& Male & 232 & 49.36 \\
Class & Female & 238 & 50.64 \\
& & & \\
& 9 & 206 & 43.82 \\
& 10 & 116 & 24.68 \\
& 11 & 148 & 31.50 \\
\hline
\end{tabular}

\section{Data Collection Tools}

\section{Conscientiousness Scale}

Benet-Martinez and John (1998) have determined the participants' levels of conscientiousness with the sub-dimension conscientiousness of The Big Five Inventory, a scale including five factors. The Big Five Inventory measures the personality with five sub dimensions as "Conscientiousness", "agreeableness", "extroversion", "neuroticism" and "openness". The scale is a five point likert scale with 44 articles. Conscientiousness dimension consists of 9 articles. Cronbach Alpha values, related to this dimension have been obtained as .78 when this scale is developed (Schmitt et al., 2007). The Big Five Inventory has been adapted to Turkish by Sumer and Sumer (2005) within the context of the study, conducted by Schmidt (2007) that aims to enable individuals to identify their own profiles in 56 countries (Basım, Çetin \& Tabak, 2009). The applicability of the structure of the Big Five Inventory model has been observed in the sample adolescent groups in Turkey as well (Korkmaz, Somer, \& Güngör, 2013). In this study, the construct validity of the scale was examined through explaratory factor analysis (EFA). According to EFA, the value of Kaise-Malkin-Olkin (KMO) is 0.771 and the value of Bartlett Test is 662.80 ( $\mathrm{p}<0.01)$. The scale explains $\% 34.63$ of the variance. The minimum factor load value is .49 and the maximum value is .68 . The highest item-total correlation coefficient is .45 and the lowest is .37. Based on these findings, it can be said that the scale is suitable for high school students. In this study, Cronbach Alpha reliability of conscientiousness dimension scale has been measured as .71.

\section{Game Addiction Scale}

The participants' digital game addiction has been identified with the game addiction scale, developed by Lemmens, Valkenburg and Peter (2009) and later adapted to Turkish by Yalçın, Irmak and Erdogan (2015) to determine the participants' problematic behaviors related to playing digital games. The scale has seven articles. It is one dimensional, and five likert type. Cronbach factor has been accounted as .72 for Turkish form and it has been reported to explain $\% 56.96$ of variation. It has been observed as a result of the confirmatory factor analysis that the scale has adapted well (Yalçın Irmak \& Erdoğan, 2015). In this study, Cronbach Alpha reliability of DGA scale has been measured as .809.

\section{Data Collection and Analysis}

The data has been collected in the classes by the teachers after the necessary permissions have been obtained. The collected data have been analyzed through the correlation and multi-linear regression methods by using SPSS. The normality condition has been provided since 476 data have been used in this study for three variations at total, including one independent variation and two dependent variations (Wooldridge, 2013). For gender, dummy variable (for the case of being male) has been used. VIF and Tolerance values have been checked for conscientiousness and gender scores. It has been determined that there is not a multicollinearity problem (VIF $<10$; Tolerance $>0.2$ ). The scatter graph of error terms has been analyzed. It has been established that the error terms have nearly normative distribution (Alpar, 2012; Tabachnick \& Fidell, 2007). Consequently, all conditions for the multi-linear regression analysis have been met. 


\section{Findings}

In this study, the point averages and the standard deviation values, obtained from the scales, used to determine the participants' levels of DGA and conscientiousness have been given in Table 2 .

Table 2

The point average of the participants' DGA and conscientiousness

\begin{tabular}{lccc}
\hline Scale & $\mathbf{N}$ & $\overline{\mathbf{x}}$ & sd. \\
\hline Conscientiousness & 470 & 4.16 & 0.58 \\
DGA & 470 & 1.71 & 0.71 \\
\hline
\end{tabular}

As can be observed in Table 2, the participants' average point in conscientiousness scale has been measured as $4.16(\mathrm{sd} .=.58)$ out of 5 . However, the participants' average point in DGA scale has been measured as $1.71(\mathrm{sd} .=.71)$ out of 5 .

The correlation analysis has been done to determine the relation between conscientiousness and DGA. The obtained Pearson correlation factor has been given in Table 3.

Table 3

Correlation analysis results that explained the relation betwen conscientiousness and DGA

\begin{tabular}{lcc}
\hline & DGA & Conscientiousness \\
\hline DGA & 1 & $-.316^{* *}$ \\
Conscientiousness & $\cdot$ & 1 \\
\hline${ }^{* *} \mathrm{p}<.01 ; \mathrm{n}=470$ & &
\end{tabular}

As can be seen in Table 3, it has been established that there is an inverse, low level but meaningful relation $(r=-.316, p<.01)$ between DGA and Conscientiousness.

In this study, multi-linear regression analysis has been applied to see the impact of gender and conscientiousness on the DGA. The acquired results have been given in Table 4.

Table 4

Regression analysis results

\begin{tabular}{lccccc}
\hline Model & B & Standard Error & Beta $(\boldsymbol{\beta})$ & t & p \\
\hline Constant & 3.114 & .228 & & 13.838 & .000 \\
Conscientiousness & -.362 & .053 & -.298 & -6.836 & .000 \\
Gender & .218 & .062 & .154 & 3.520 & .000 \\
\hline
\end{tabular}

$\mathrm{F}_{(2-470)}=32.731 ; \mathrm{p}=0.000 ; \mathrm{R}=.351 ; \mathrm{R}^{2}=.123 ;$ Gender $(1=$ male; $0=$ female $)$

As can be seen in Table $4, \mathrm{~F}$ value in relation to regression model is statistically meaningful $(\mathrm{F}=$ $32.731 ; \mathrm{p}<.01)$. Therefore, it is possible to say that regression model has predicted the DGA meaninfully (Büyüköztürk, 2011). The participants' conscientiousness level and gender (being male) have shown a meaningful relation with DGA $\left(\mathrm{R}=0.351 ; \mathrm{R}^{2}=0.123, \mathrm{p}<.01\right)$. Both variables together are able to explain $\% 12$ of the change on the DGA.

In the t-test results in relation to the meaningfulness of the regression factors $(\beta)$, both conscientiousness and gender variables are seen in Table 4 as the meaningful predictors of the DGA $(p<0.01)$. According to the standardized regression factors, The relative order of importance of the predictor-variables has been determined as conscientiousness and gender (being male). According to the multi-regression anlaysis result, The regression equation in relation to the prediction of DGA score is as follows:

$$
D G A=3.114+(-0.362) \times \text { Conscientiousness Score }+(0.218) \times \text { Gender }(1=\text { male } ; 0=\text { female })
$$

\section{Discussion and Results}

This study has been conducted to determine the relation between the conscientiousness as a personality trait and DGA in high school students. It has also aimed to see the impact of 
conscientiousness and gender on the DGA. In this study, it has been established that there is an inverse, low level and statistically meaningful relation between the DGA and conscientiousness. Accordingly, the decrease in the conscientiousness level has caused an increase in the DGA. In the regression analysis, conducted, it has been established that conscientiousness and gender are the meaningful predictors of the DGA and both variables together have explained $\% 12.3$ of the change on the DGA.

In this research, it was determined that the low level of conscientiousness has a negative effect on the DGA. This finding is compatible with other studies' findings in literature that have explained the relation the adults' conscientiousness and the DGA (Batıün \& Kiliç, 2011; Kim et al., 2008). In another study, it has been established that the adults who join the social network for playing games have meaningfully lower conscientiousness scores than the ones who join the social networks for other purposes (Seviniş \& Bilgin, 2017). This finding is such as to support the finding of this research. Çelik, Atak \& Başal (2012), Kayiş et al. (2016), Rahmani \& Lavasani, 2011; Randler, Horzum \& Vollmer (2014), Servidio (2014), Taş \& Ayas (2015) and Van der Aa et al. (2009) found a relationship between internet addiction and conscientious; likewise, this study found a correlation between DGA and digital addiction. Internet addiction and DGA can be assessed under the category of digital addiction. Therefore, it can be said that these studies support our research findings. However, another study that was conducted on teachers found that conscientiousness is not meaningful predictor of the DGA (Aydın \& Horzum, 2015). The reason for this difference might be because of the choice of the sample consisting of adults with a high level of conscientiousness.

In the study, it has been observed that gender is a meaningful predictor of the DGA. It has also been found out that gender (for males) has a positive effect on the DGA. This finding is such as to support the views that gender is a remarkable element in the DGA (Nazligül et al., 2018; Király et al., 2018; Ko at al., 2005; Chou \& Tsai, 2007). Moreover, it has been noticed that this finding of the study is compatible with other studies that have been conducted on the various samples such as primary and secondary school students (Gökçearslan \& Durakoğlu, 2014; Horzum, 2011; Li \& Wang, 2013; Turner et al., 2012), and university students (Çakır, Ayas \& Horzum, 2011). It has been explained that the liability to the DGA in males depends not only on the males' higher desire for sense of achievement and communication but also on their higher motivation for playing games than the females have. In addition to this, males' liability to the DGA has been explained in the cultural context. It has been noted that the females have been much more exposed to the cultural imposition than males and that this fact has posed an obstacle before females' playing games (Ko et al., 2005). This argument can be said to be compatible with the cultural characteristics of the sample on whom the study has been conducted. In a study that has been conducted on teachers, gender has been determined as not one of the predictors of the DGA (Aydın \& Horzum, 2015). This finding is thought to result from a specific sample with high level of conscientiousness. Similarly, there are also studies that have argued gender is not an effective variable on the DGA (Kim et al., 2008; Taş, Eker \& Anlı, 2014).

In this study, it has been concluded that the students with low level of conscientiousness and male students are more liable to the DGA. Accordingly, it can be said that the adolescents with low level of conscientiousness and male students are risk factors in terms of the DGA. Developing the sense of conscientiousness in individuals will protect them against the DGA. For this reason, the high school students' traits of conscientiousness must be developed. Sense of responsibility is related to conscientiousness (Costa \& McCrae, 1995). In literature, it has been reported that the educational programs that aim to develop the sense of responsibility have had successful outcomes (Acar, 2012; Howard, 2005; Dilmaç, 2007). Therefore, the traits of conscientiousness might be developed by enhancing the adolescents' sense of responsibility, and hence some positive outcomes can be acquired against the DGA. Considering this protective side of developing the sense of conscientiousness, the teachers and parents should be informed about its protective effect against the DGA. Also, some studies must be carried out about what things can be done in order to raise individuals with a good sense of responsibility. 


\section{References}

Acar, M.C. (2012). The effect of existentialist-oriented approach responsibility programme onto eighth class primary school students responsibility level (Unpublished master's thesis). Gaziantep University, Gaziantep.

Alpar, R. (2012). Applied statistics and validity-reliability with examples from sports, health and education sciences (Spor, sağllk ve eğitim bilimlerinden örneklerle uygulamalı istatistik ve geçerlilik-güvenirlik (2 ${ }^{\text {th }}$ Ed.). Ankara: Detay.

Ayas, T. (2012). The relationship between internet and computer game addiction level and shyness among high school students. Educational Sciences: Theory and Practice, 12(2), 632-636.

Aydın, F., \& Horzum, M. B. (2015). Investigation of predictive variables of computer game addiction level of teachers. Online Journal of Technology Addiction \& Cyberbullying, 2(1), 52-66.

Basım, H. N., Çetin, F., \& Tabak, A. (2009). The relationship between big five personality characteristics and conflict resolution approaches. Turkish Journal of Psychology, 24(63), 3537 .

Batıgün, A. D., \& Kiliç, N. (2011). The relationships between internet addiction, social support, psychological symptoms and some socio-demographical variables. Turkish Journal of Psychology, 26(67), 1.

Bayırtepe, E., \& Tüzün, H. (2007). The effects of game-based learnıng environments on students' achievement and self-efficacy in a computer course. H. U. Journal of Education, 33, 41-54.

Büyüköztürk, Ş. (2011). Manual of data analysis for social sciences (Sosyal bilimler için veri analizi el kitabi), (15 $5^{\text {th }}$ Ed.). Ankara: Pegem.

Can, G. (2014). Personality development (Kişilik gelişimi) B. Yeşilyaprak (Ed.) Education psychology (Eğitim Psikolojisi). Ankara: Pegem.

Charlton, J. P., \& Danforth, I. D. (2010). Validating the distinction between computer addiction and engagement: Online game playing and personality. Behaviour \& Information Technology, 29(6), 601-613.

Chou, C., \& Tsai M. J. (2007). Gender differences in Taiwan high school students' computer game playing. Computers in Human Behavior, 23(1), 812-824.

Costa Jr, P. T., \& McCrae, R. R. (1995). Domains and facets: Hierarchical personality assessment using the Revised NEO Personality Inventory. Journal of Personality Assessment, 64(1), 2150 .

Costa, P. T., McCrae, R. R., \& Dye, D. A. (1991). Facet scales for agreeableness and conscientiousness: A revision of the NEO Personality Inventory. Personality and individual Differences, 12(9), 887-898.

Çakır, Ö., Ayas, T., \& Horzum, M. B. (2011). An investigation of university students' internet and game addiction with respect to several variables, Ankara University, Journal of Faculty of Educational Sciences, 44(2), 95-117.

Çelik, S., Atak, H, \& Başal, A. (2012). Predictive role of personality traits on internet addiction. Turkish Online Journal of Distance Education, 13(4), 10-24.

Dilmaç, B. (2007). The assesment of the teaching of humane values which are imposed a group of science high school students by humane values scale (Unpublished doctoral thesis). Selçuk University, Konya.

Garris, R., Ahlers, R., \& Driskell, J.E. (2002). Games, motivation, and learning: A research and practice model. Simulation and Gaming, 33, 441-467. 
Gökçearslan, Ş., \& Durakoğlu, A. (2014). An analysis of video game addiction levels among secondary school students according to several variables, Dicle University Journal of Ziya Gökalp Faculty of Education, 23, 419-435.

Griffiths, M. D., Kuss, D. J., \& King, D. (2012). Video game addiction: past, present and future. Current Psychiatry Reviews, 8(4). http://dx.doi.org/10.2174/ 157340012803520414.

Gürcan, A., Özhan, S., \& Uslu, R. (2008). Digital games and effects on children (Dijital oyunlar ve çocuklar üzerindeki etkileri). Prime Ministry General Directorate of Family and Social Research (Başbakanlık Aile ve Sosyal Araştırmalar Genel Müdürlüğ̈̈), Ankara, 1-50.

Horzum, M. B. (2011). Examining computer game addiction level of primary school students in terms of different variables. Education and Science, 36(159), 56-68.

Hewitt, M., Denman, S., Hayes, L., Pearson, J., \& Wallbanks, C. (2001). Evaluation of 'Sun-safe': A health education resource for primary schools. Health Educ. Res. 16(5), 623-633.

Howard, T. A. (2005). The effects of a responsibility- based character education program on middle school academic achievement and school climate at an international school in East Africa (Unpublished doctoral thesis). University of Central Florida, Florida.

Irmak, A. Y., \& Erdoğan, S. (2016). Digital game addiction among adolescents and younger adults: A current overview. Turkish Journal of Psychiatry, 27(2), 1-11.

Johnston, J.D., Massey, A.P., Marker-Hoffman, R.L. (2012). Using an alternate reality game to increase physical activity and decrease obesity risk of college students. Journal of Diabetes Science and Technology, 6(4), 828-838.

Karasar, N. (2014). Bilimsel araştırma yöntemi. Ankara: Nobel.

Kato, P. M., Cole, S. W., Bradlyn, A. S., \& Pollock, B. H. (2008). A video game improves behavioral outcomes in adolescents and young adults with cancer: A randomized trial. Pediatrics, 122, 305-317.

Kayiş, A. R., Satici, S. A., Yilmaz, M. F., Şimşek, D., Ceyhan, E., \& Bakioğlu, F. (2016). Big fivepersonality trait and internet addiction: A meta-analytic review. Computers in Human Behavior, 63, 35-40.

Kesici, A., \& Tunç, N. F. (2018). The development of the Digital Addiction Scale for the university students: Reliability and validity study. Universal Journal of Educational Research, 6(1), 9198.

Kılıç, S. (2013). Sampling methods. Journal of Mood Disorders, 3(1), 44-46.

Kim, E. J., Namkoong, K., Ku, T., \& Kim, S. J. (2008). The relationship between online game addiction and aggression, self-control and narcissistic personality traits. European Psychiatry, 23(3), 212-218.

Király, O., Griffiths, M. D., Urbán, R., Farkas, J., Kökönyei, G., Elekes, Z., \& Demetrovics, Z. (2014). Problematic internet use and problematic online gaming are not the same: findings from a large nationally representative adolescent sample. Cyberpsychology, Behavior, and Social Networking, 17(12), 749-754.

Ko, C. H., Yen, J. Y., Chen, C. C., Chen, S. H., \& Yen, C. F. (2005). Gender differences and related factors affecting online gaming addiction among Taiwanese adolescents. The Journal of Nervous and Mental Disease, 193(4), 273-277.

Korkmaz, Somer, \& Güngör (2013). Measurement equivalence across gender with mean and covariance structure of five factor personality inventory for adolescent sample. Education and Science, 38(170).

Li, H., \& Wang, S. (2013). The role of cognitive distortion in online game addiction among Chinese adolescents. Children and Youth Services Review, 35, 1468-1475. 
Nazlıgül, M. D., Baş, S., Akyüz, Z., \& Yorulmaz, O. (2018). Internet gaming disorder and treatment approaches: A systematic review. Addicta: The Turkish Journal on Addictions, (5), 13-35.

Prot, S., Anderson, C. A., Gentile, D. A., Brown, S. C., \& Swing, E. L. (2014). The positive and negative effects of video game play. Media \& the Well-Being of Children \& Adolescents, 109128.

Rahmani, S., \& Lavasani, M. G. (2011). The relationship between internet dependency with sensation seeking and personality. Procedia-Social and Behavioral Sciences, 30, 272-277.

Randler, C., Horzum, M. B., \& Vollmer, C. (2014). Internet addiction and its relationship to chronotype and personality in a Turkish university student sample. Social Science Computer Review, 32(4), 484-495.

Sardoğan, M. E., \& Karahan T. F. (2011). Personality development (Kişilik gelişimi) A. Kaya (Ed.) Education psychology (Eğitim Psikolojisi). Ankara: Pegem.

Servidio, R. (2014). Exploring the effects of demographic factors, Internet usage and personality traits on Internet addiction in a sample of Italian university students. Computers in Human Behavior, 35, 85-92.

Seviniş, S., \& Bilgin, M. (2017). The relationship between adult's social network use and five factors personality traits. Journal of Human Sciences, 14(4), 3126-3157.

Schmitt, D. P., Allik, J., McCrae, R. R., \& Benet-Martínez, V. (2007). The geographic distribution of Big Five personality traits: Patterns and profiles of human self-description across 56 nations. Journal of cross-cultural psychology, 38(2), 173-212.

Somer, O. (1998). The structure of adjectives defining the personality trait in Turkish and the five factor model (Türkçe'de kişlilik özelliği tanımlayan sıfatların yapısı ve beş faktör modeli). Turkish Journal of Psychology, 13(42), 17-32.

Somer, O., Korkmaz, M., \& Tatar, A. (2004). Five-factor personality model and five-factor personality inventory to quasi-practice (Kuramdan uygulamaya beş faktör kişilik modeli ve beş faktör kişilik envanteri 5FKE). İzmir: Ege University Press.

Schmitt, D. P., Allik, J., McCrae, R. R., \& Benet-Martinez, V. (2007). The geographic distribution of big five personality traits: Patterns and profi les of human self-description across 56 nations. Journal of Cross-Cultural Psychology, 38(2), 173-212.

Tabachnick, B. G. V. \& Fidell, L. S. (2007). Using multivariate statistics (5'th Ed.). U.S.A: Pearson Education Inc.

Taş, İ., Eker, H. \& Anlı, G. (2014). Investigation of internet and game dependency levels of secondary education students (Orta öğretim öğrencilerinin internet ve oyun bağımlılık düzeylerinin incelenmesi). Online Journal of Technology Addiction \& Cyberbullying, 1(2), 37-57.

Taş, İ., \& Ayas, T. (2015). Relationship the level of internet addiction with personality traits of high school students. Journal of Human Sciences, 12(2), 150-162.

Tatlllığlu, K. (2014). A research subscales of undergraduates' personality traits according to five factor personality theory in terms of some variants. Journal of History School (JOHS), 7(17), 939-971.

Turner, N. E., Paglia-Boak, A., Ballon, B., Cheung, J. T. W., Adlafi E. M., Henderson, J., Chan, V., Rehm, J., Hamilton, H., \& Mann, R. E. (2012) Prevalence of problematic video gaming among Ontario adolescents. International Journal of Mental Health and Addiction, 10(6), 877-889.

Van der Aa, N., Overbeek, G., Engels, R. C., Scholte, R. H., Meerkerk, G. J., \& Van den Eijnden, R. J. (2009). Daily and compulsive internet use and well-being in adolescence: a diathesis-stress model based on big five personality traits. Journal of youth and adolescence, 38(6), 765-776. 
Wooldridge, J. M. (2013). Introductory econometrics: A modern approach. (Ekonometriye giriş: Modern yaklaşım, dördüncü baskıdan çev.). E. Çağlayan (Ed.). Ankara:Nobel.

Yalçın Irmak, A., \& Erdoğan, S. (2015). Validity and reliability of the Turkish version of the Digital Game Addiction Scale. Anatolian Journal of Psychiatry, 16(1), 10-18. DOİ: 10.5455/apd.170337.

Young, K. (2009). Understanding online gaming addiction and treatment issues for adolescents. The American Journal of Family Therapy, 37(5), 355-372. 
